\title{
THE FOURTH INDUSTRIAL REVOLUTION: A CASE FOR EDUCATIONAL TRANSFORMATION
}

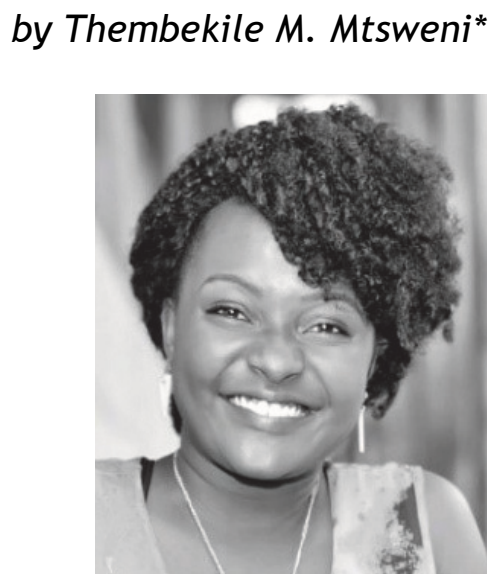

'Every industrial revolution brings along a learning revolution' Alexander De Croo

\section{Introduction}

The fourth industrial revolution (the $4^{\text {th }} I R$ ) is a technological innovation whose velocity, scale, scope, complexities and transformative power will be nothing like anything humankind has experienced before. ${ }^{1}$ In the paradigm of the $4^{\text {th }} \mathrm{IR}$, automation and artificial intelligence will disorganise the current model of demand for skills, ensuring rapid replacement of traditional jobs with new unknown ones. ${ }^{2}$ These new jobs will be characterised by high-level cognitive and social interaction skills. ${ }^{3}$ Standardised, routine and manual tasks will be left to robotic and artificial intelligence. ${ }^{4}$ This unprecedented wave of change will cause problems in countries

* $\quad$ Fourth year LLB student, University of Pretoria. ORCID: 0000-0003-4319-0687.

1 M Marope 'Reconceptualizing and repositioning curriculum in the 21st Century: A global paradigm shift' (2017) International Bureau of Education 23.

2 Marope (n 1 above) 23.

3 International Bureau of Education ILO and OECD Report Global Skills Trends, Training Needs and Lifelong Learning Strategies for the Future of Work (2019) 2 https://www.ilo.org/wcmsp5/groups/public/---dgreports/----inst/documents/ publication/wcms_646038.pdf (accessed on 18 October 2019).

$4 \quad$ ILO and OECD Report (n 3 above) 5. 
where the demand for high-level skills is rising faster than the supply. ${ }^{5}$ Owing to their lack of relevant skills, people will lose jobs and not be able to find new ones. The recent retrenchment plight involving South African banks evidences the kind of dilemma people will be subjected to in this evolving world of work. Absa, Standard Bank and Nedbank Group have all consulted with their staff members about cuts in recent months. ${ }^{6}$ These banks closed some of their branches due to economic pressure to encourage self-service instead, with clients using their mobile phones and computers, rather than physically walking into a branch to access banking services. ${ }^{7}$ Many people have already lost their jobs and yet, plans to get rid of more tellers still continue as the banking industry evolves. ${ }^{8}$ Loss of jobs in this regard can easily be attributed to the fact that banking tellers' skills are slowly losing relevance due to digitalisation. General Secretary of the South African Society of Bank Officials, Joe Kokela, stated in an interview that 'Absa is restructuring operations across its business units; Standard Bank is closing 91 branches, while Nedbank is in talks with about 1,500 employees over job cuts or redeployments'. South Africa's unemployment rate stands at 29.1\% of which 55.2\% consist of our youth. ${ }^{10}$ Banking Association South Africa (BASA) gave the following remarks with respect to these changes in the banking industry: ${ }^{11}$

The global banking industry is evolving in response to economic pressures, digital innovation and, most importantly, the changing way their customers use and consume financial services. The reduction of staff numbers in many traditional banking services is a worldwide phenomenon.

Deputy President, David Mabuza recently responded to a question in Parliament involving what 'the plans of government are in ensuring alignment of education with the $4^{\text {th }}$ IR for the production of relevant human resources'. ${ }^{12}$ He alluded, inter alia, that government will need to direct its focus to: realignment of the curriculum at basic education level to prepare learners for the changing world; the introduction of several new technological subjects; and the specialisation and training of teachers to respond to the emerging technologies including

$5 \quad$ ILO and OECD Report (n 3 above) 12.

6 SASBO NEWS 'Why the Strike' May/June 2019 https://www.sasbo.org.za/sasbonews-vol-41-no-3/ (Accessed on the 28th October 2019).

7 As above.

8 As above.

9 As above.

10 SASBO NEWS ‘4IR humanity needed’ May/June 2019 https://www.sasbo.org.za/ sasbo-news-vol-41-no-3/ (accessed 28 October 2019).

11 The Banking Association South Africa 'SASBO Protest' 23 September 2019 https: / / www.banking.org.za/news/19-sept-sasbo-protest/ (accessed 15 October 2019).

12 Government of the Republic of South Africa Newsroom 'Deputy President David Mabuza: Response to questions in Parliament' 27 February 2019 https://www. gov.za/speeches/deputy-president-david-mabuzaresponds-questions-parliament27-feb-2019-0000 (accessed 15 October 2019). 
the internet of things, robotics and artificial intelligence. ${ }^{13}$ With the destruction of traditional jobs and the rise of new ones, a fundamentally important and urgent need of new competencies is mounting. Any such need for new skills and competencies can only be adequately catered for by education and skills training. Basic education will have to play an imperative role in the curbing of the many challenges that the changing world of work is threatening us with. Education will have to be adequate enough to ensure optimum contribution of curriculum in meeting demands and opportunities in light of the $4^{\text {th }}$ IR. ${ }^{14}$ Only a relevant, responsive, and foresighted education, whose anticipator capacity is capable of catering for present and future needs of the people will be able to assist people to adapt to the changing world of work. An anticipatory education system is one capacitated with built-in mechanisms and sub-systems that allow for constant self-renewal, adaptation and innovation, in order to maintain relevance with the changing world. Contrary to traditional education reform duration, which takes years on end, an anticipatory education is more fast paced in its response to environmental changes, and sometimes it also plays a proactive role to change.

Needless to say, the $4^{\text {th }}$ IR will affect humankind at all different levels and facets of life. Preparation thus will have to engage as many stakeholders as necessary including those in political, economic and social spheres. However, a case here is made for preparation for the $4^{\text {th }}$ IR specifically at the level of basic education. This case is significant for two reasons: Firstly, any focus away from children today will build an entire generation of children without the cognitive skills necessary to tackle the new world presented by the $4^{\text {th }}$ IR. Children are especially vulnerable to the kind of education conveyed to them because they are unable to distinguish between an education system that caters for their best interest and one that does not. ${ }^{15}$ Consequently, they are at the mercy of those who have the power to act on their behalf. The government must ensure that children are not jobless and poor in the near future merely because they are unemployable owing to the calibre of education they received. This would not be harmonious with the purpose of education which is to empower children not just for the present, but for the future as well. Secondly, an irrelevant education should be deemed an infringement on children's constitutional right to education in as far as it is preparing them for a world that will not be in existence when they

13 As above.

14 Marope (n 1 above) 25.

15 S Woolman and $M$ Bishop 'Education' in S Woolman and others (eds) Constitutional Law of South Africa (2013 $2^{\text {nd }}$ edition) 57. 
leave school. ${ }^{16}$ If the latter is true, the courts must be in a position to give a corresponding order for the immediate enforcement of the right to basic education where the executive fails to carry out its mandate to provide for education relevant for the $4^{\text {th }}$ IR.

In this article, I use the aims and objects of education to argue that educational empowerment involves skills development for $4^{\text {th }}$ IR. At the backdrop of the meaning of 'basic education', I argue that any lack of adequate educational preparation for the $4^{\text {th }}$ IR is an infringement on children's constitutional right to basic education. Considering the wealth of jurisprudence centring on the right to basic education, it is further demonstrated that courts might be reluctant to grant remedies for the immediate realisation of curriculum change and other like-measures relevant for the $4^{\text {th }}$ IR. This reluctancy is an aftermath of policy considerations to keep powers of the different arms of government purely separate.

The conclusion reached is that: If the current judicial interpretive inflexibility and narrowness in approach to the right to basic education is maintained, and if this right is not fully fleshed out by the time the $4^{\text {th }}$ IR is in full swing, the judiciary will not have an adequate, receptive and accommodating body of jurisprudence to refer to and rely on when adjudicating for educational changes required by the $4^{\text {th }}$ IR. Courts will thus not be willing or positioned to find violations of the right as per the new de facto standards of the $4^{\text {th }}$ IR. Consequences of this are: In the intermediate, the courts are unlikely or, on the jurisprudential approach, even unable, to find violations of the right to education where the Department of Education fails to take the necessary steps to give effect to the right; and that, given this judicial reticence and fettering, the jurisprudential position may continue to lag behind the dynamic lead of (global?) educational development in the wake of the $4^{\text {th }}$ IR, meaning that the Department will likely not be compelled to catch-up to $4^{\text {th }}$ IR progress if or when it, too, lags. And, assuming that landmark cases shift the jurisprudence on the right to education so as to catch-up to the $4^{\text {th }} I R$, outpacing a Department of Education which has been compliant with then previous jurisprudential standards, given the current and intermediate judicial reticence and fettering, the courts could plausibly then be left in a position of potentially ordering the executive to do the impossible and make-up the difference between a lagging education system and the $4^{\text {th }}$ IR revolutionary requirements.

16 S29(1)(a) of the Constitution of the Republic of South Africa, 1996 (the Constitution) states that everyone has the right to a basic education, including adult basic education. 


\section{Education, empowerment and skills development}

Donnelly and Howard in their assessment of human rights in the Bill of Rights of South Africa investigated what purpose each right in the Bill of Rights serves. They identified four groups within which rights can be categorised. They argue that rights can be aimed at: (1) survival of the people (e.g. the right to life, food and health care); (2) membership of the people (e.g. the right to equality and family rights); (3) protection of the people (e.g. habeas corpus and independent judiciary); and (4) empowerment of the people (e.g. the right to education, association and expression). ${ }^{17}$ Education is categorised as an empowerment right. This interpretation of education as empowerment finds great support in international law. The United Nation Committee on Economic, Social and Cultural Rights (the UN Committee on the ESCR) in its commentary on the right to basic education stated the following: ${ }^{18}$

Education is both a human right in itself and an indispensable means of realizing other human rights. As an empowerment right, education is the primary vehicle by which economically and socially marginalized adults and children can lift themselves out of poverty and obtain the means to participate fully in their communities ... education is recognized as one of the best financial investments States can make.

The right to basic education serves as an empowerment right in two identified ways. ${ }^{19}$ Firstly, it enables citizens 'to set rules of the game, and not merely be assured that the rules are applied as written'.20 Secondly, it 'allows the individual to determine the shape and direction of his or her life'. ${ }^{21}$ It also facilitates the enjoyment of other constitutional rights. Many socio-economic rights such as the right to equal-work-for-equal-pay and the right to collectively bargain can only be exercised in a meaningful way after a minimum level of education has been achieved. ${ }^{22}$ Education enables people to voyage freely in the world to create a meaningful life for themselves and those around them. It liberates and it empowers. It is impossible to imagine education without empowerment. If education is educating at all, those subject to it should be empowered to participate in their communities in meaningful and rewarding ways. More emphasis must be put on the understanding and enforcement of the right to education as an empowerment right, having an empowerment

J Donnelly and $\mathrm{R}$ Howard 'Assessing national human rights performance: A theoretical framework'(1988) 10 Human Rights Quarterly 214.

18 Article 13 of the International Covenant on Economic, Social and Cultural Rights, 1966 (ICESCR).

19 Donald and Howard (n 17 above) 234.

20 Donald and Howard (n 17 above) 235.

21 As above.

22 As above. 
function outside which education is impossible. Education is essential for socio-economic development: when individuals are duly educated, they have a greater chance to secure both the basic necessities for survival and other material goods required for flourishing. ${ }^{23}$

The attainment of empowerment should be judged against the constantly evolving society and societal needs. Education must assist human beings to constantly evolve and grow to secure their continued existence in societies. When education is not malleable, empowerment will certainly be compromised when change engulfs the spaces for which people are being educated. In the Constitutional Court case of Governing Body of the JumaMusjid Primary School $v$ Essay (JumaMusjid), ${ }^{24}$ Nkabinde J summarised the empowering effect of the right to education as follows: ${ }^{25}$

Basic education is an important socioeconomic right directed, among other things, at promoting and developing a child' features personality, talents and mental and physical abilities to his or her fullest potential. Basic education also provides a foundation for a child's lifetime learning and work opportunities.

If children are not taught in such a way so as to have the abilities and skills required to secure or create employment opportunities in the near future and if ultimately, they are unable to provide for their basic necessities for survival due to the same, then we cannot speak of having educated them. There is no purpose served by an education, and entitlement to education, whose subjects are certified but unable to feed themselves and their families mainly because they are not prepared for the kind of work available in their labour market. This means education should be rejected if it lacks the necessary skills development and preparation for one's life. Education systems in South Africa must provide good foundational skills as well as reskilling and upskilling opportunities for the $4^{\text {th }}$ IR. ${ }^{26}$ In terms of basic education, skills imbalances should inform changes in teaching methods and curriculum content to ensure that high-level problem solving, critical thinking, and the ability to manage complex social interactions are developed. ${ }^{27}$ This empowerment function of education underpins the greater protection that the right to education receives in comparison to other socio-economic rights under the Constitution. ${ }^{28}$ The constitutional assembly believed that: ${ }^{29}$

23 As above.

242011 (8) BCLR 761 (CC).

25 JumaMusjid (n 24 above) para 42.

26 ILO and OECD Report (n 3 above) 22.

27 ILO and OECD Report (n 3 above) 14.

28 Woolman and Bishop (n 15 above) 57.16.

29 As above. 
An adequate education provides the quickest route to a polity of a creative, productive and self-sufficient population of citizens-and not a country in which the majority of decisions relied on some form of state largesse.

When the empowerment goal of education is attained, only then will the state be said to have disposed of its obligation for the provisioning of education.

\section{The meaning of the right to basic education}

The courts are yet to interpret the meaning of the term 'basic education'. ${ }^{30}$ There are two possible interpretations of this term. ${ }^{31}$ It could either refer to a specific period of schooling (i.e. primary school) or it could refer to a certain standard of education, namely its quality or adequacy. ${ }^{32}$ The Constitutional Court in JumaMusjid has been criticised for following the quantitative interpretation when deciding the meaning and scope of the right to basic education. ${ }^{33}$ In casu, the meaning of 'basic' was woven into the fabric of section 3(1) of the South African Schools $\mathrm{Act}^{34}$ which makes attendance of school compulsory for children from the ages of 7 years until 15 years or until grade 9 , whichever comes first; 35 and the Court's reasoning was woven into the fabric of the words used in section 29 of the Constitution which distinguishes between basic and further education. ${ }^{36}$ Academic critics have argued that the court erred in its interpretation of the meaning of basic education when it defined the parameters of the right by limiting education to a number of years. ${ }^{37}$ Skelton, in criticising the Jumamusjid interpretation of the term 'basic', argues that such a narrow interpretation can easily be misused in pursuit of limiting the financial impact of the right to basic education. ${ }^{38}$ Such misuse can easily be perpetuated since courts have not yet pronounced on whether a child who is older than 15 years and yet beyond grade 9 is entitled to enjoy the right to basic education. 39 Neither has anything been said about the educational rights of a child younger than 15 but above grade 9. A court might rely on the JumaMusjid interpretation to find that the state has no obligation

30 A Skelton 'How far will the courts go in ensuring the right to a basic education?' (2012) 27 South African Public Law 403.

31 Woolman and Bishop (n 15 above) 57.15.

32 Woolman and Bishop (n 15 above) 57.16.

33 JumaMusjid (n 24 above) para 42.

3484 of 1996.

35 JumaMusjid (n 24 above) para 38.

36 Sec 29 of the Constitution; JumaMusjid (n 24 above) para 38; South African Schools Act 84 of 1996.

37 A Skelton 'The role of courts in ensuring the right to a basic education in a democratic South Africa: A critical evaluation of recent education case law' (2013) De Jure 1.

38 Skelton (n 30 above) 403.

39 As above. 
towards these children. ${ }^{40}$ Thus it seems that to follow such an interpretation would limit the right to education. Other reasons which have been advanced against the quantitative interpretation of basic education include that the wording of section 29(1)(a) makes the right to basic education to extend to adults as subjects to the right to basic education, making it impossible to confine basic education to particular ages, or to time spent in school. ${ }^{41}$ The JumaMusjid interpretation which links basic education to a period of school as opposed to the quality of education received by learners was only mentioned in obiter dicta; the Court was not required to determine what is meant by 'basic education'. ${ }^{42}$ Its interpretation will therefore not prevent another court from elaborating on the right to education with emphasis on its qualitative meaning. ${ }^{43}$ It is thus justified, from observing policy and previous precedents, to say that the quantitative approach to basic education has found little to no support in our jurisprudence. A more acceptable interpretation of the right to basic education focuses not on the number of years within which education is provided but rather on the quality or adequacy of the education that the child receives. ${ }^{44}$ Woolman and Fleisch have argued that international law can be invoked to support an interpretation of basic education that relates to content, and not duration. 45 The origin of the phrase 'basic education' can be traced back to 1990 where it was included in the World Declaration on Education for All. ${ }^{46}$ Article 1 of the World Declaration explains that the right to a 'basic education' is a guarantee that: ${ }^{47}$

Every person - child, youth and adult - shall be able to benefit from educational opportunities designed to meet their basic learning needs. These needs comprise both essential learning tools (such as literacy, oral expression, numeracy, and problem solving) and the basic learning content (such as knowledge, skills, values, and attitudes) required by human beings to be able to survive, to develop their full capacities, to live and work in dignity, to participate fully in development, to improve the quality of their lives, to make informed decisions, and to continue learning.

In June 1995, South Africa ratified the United Nations Convention on the Rights of the Child. ${ }^{48}$ The United Nations Committee on the Rights

40 As above.

41 Skelton (n 30 above) 403.

42 Skelton (n 30 above) 403-404.

43 As above.

44 C McConnachie et al 'The Constitution and the right to a basic education' in R Veriana and A Thoom (eds) Basic Education Rights Handbook (2017) 23.

45 As above. According to sec 39(1)(b) of the Constitution, when a court interprets any right in the Bill of Rights, including sec 29, and therefore when a court determines the meaning of the qualification 'basic' in sec 29 , the court must consider international law.

46 Skelton (n 30 above) 404.

47 Article 1 of the World Declaration on Education for All (1990).

48 As above. 
of the Child (UNCRC) General Comment 1, regarding the aims of education, states that the child's right to education is not only a matter of access, but also content. ${ }^{49}$ Article 29(1) focuses on the individual and subjective right to a specific quality education. ${ }^{50}$ According to the latter, 'basic skills' include: ${ }^{51}$

not only literacy and numeracy but also life skills such as the ability to make well-balanced decisions, to resolve conflicts in a non-violent manner, to develop a healthy life-style, good social relationships and responsibility, critical thinking, creative talents and other abilities which give children the tools needed to pursue their options in life.

Section 39(1)(c) of the Constitution states that when interpreting the Bill of Rights, a court, tribunal or forum may consider foreign law. ${ }^{52}$ In Campaign for Fiscal Equity Inc $v$ The State of New York it was held that: ${ }^{53}$ 'a sound basic education should not be linked to completing a certain number of grades, but rather to a measurable goal'. ${ }^{2}$ The Court alluded further that education had to enable people to obtain competitive employment and full civil participation. ${ }^{55}$ In another foreign judgment, Pauley $v$ Kelly, ${ }^{56}$ the West Virginia Supreme Court also adopted a qualitative interpretation of the right to basic education by handing down a detailed list of 'scholastic and societal achievements that a thorough and efficient education system should produce', including among other things, a knowledge of government, self-knowledge and knowledge of the environment, work training, recreational pursuits, creative arts and social ethics. ${ }^{57}$ A study of recent South African courts' adjudication of the right to basic education now shows that the pendulum in our jurisprudence favours quality-based education. In Western Cape Forum for Intellectual Disability $v$ Government of the Republic of South Africa, ${ }^{58}$ the High Court used a qualitative analysis of the right to basic education, when it required that basic education for learners with intellectual disabilities should be made adequately suited for their needs. ${ }^{59}$ The Court alluded that a learner should receive an education that 'will enable him or her to make the best possible use of his or her inherent and potential capacities; physical, mental and moral, however limited these capacities may be'. ${ }^{60}$ In Madzodzo $v$ Minister of Basic

UNCRC Committee General Comment 1 on the Aims of Education (2001) (UN Doc. CRC/GC/2001/1) para 9.

As above.

As above.

Sec 39(1)(c) of the Constitution.

100 NY 2d 893; Skelton (n 30 above) 405.

As above.

As above.

255 SE 2d 859 (1979).

The court spelt out these requirements more fully at para 39 of the judgment. See Skelton (n 23 above) 405.

(5) SA 87 (WCC).

As above.

As above. 
Education, ${ }^{61}$ the Court stated the following in relation to the right to basic education:

The state's obligation to provide a basic education as guaranteed by the Constitution is not confined to making places available at schools. It necessarily requires the provision of a range of educational resources: schools, classrooms, teachers, teaching materials, and appropriate facilities for learners.

The Court followed a qualitative interpretation in its judgment when it shifted its focus from the availability of school places, to determining what are the essentials that must not be compromised when providing for basic education. ${ }^{62}$ Most recently, the Supreme Court of Appeal confirmed that every learner has the right to adequate textbooks. ${ }^{63}$ This is intrinsic to their right to basic education. ${ }^{64}$ If the right to a basic education was only concerned with the period of schooling, that is the completion of a certain number of years in a place of school, it would have nothing to say about the developmental needs of learners.

\section{Realisation of quality basic education}

How then is quality basic education determined and how can it be tested? Put differently, what are the measures in place to determine what education is inadequate and therefore an infringement on a child's right to basic education? 'How basic is basic' in relation to the content of the right to basic education? 'What must be made available immediately and at no cost to provide for basic education?'. ${ }^{65}$

In international law, the 'minimum core' approach has received ample support in determining the content of adequate basic education. The International Convention on Economic, Social and Cultural Rights (ICESCR) in clarifying the right to basic education, defined the minimum core as 'the minimum essential levels of a right'. ${ }^{6}$ Yacoob J described it as 'the floor beneath which the conduct of the state must not drop if there is to be compliance with the obligation'. ${ }^{67}$ The minimum core of a right means that if a state fails to provide for certain defined minimum standards, such failure would prima facie constitute a violation of that state's international obligation in terms of that particular right. ${ }^{68}$ The UN Committee on

612014 (3) SA 441 (ECM).

62 As above.

63 As above.

64 Minister for Basic Education v Basic Education for All 2016 (4) SA 63 (SCA) para 41.

65 T Boezaart Child law in South Africa (2017) 519.

66 As above.

67 Minister of Health and others v Treatment Action Campaign and others 2002 (5) SA 721 (CC) para 31.

68 Boezaart (n 65 above) 518. 
the ESCR issued a general comment regarding the right to education as well as its regime. ${ }^{69}$ The UN Committee on the ESCR's General Comment 13 states that parties to the ICESCR are obliged to ensure the 'Availability, Accessibility, Acceptability, and Adaptability' of education, 70 otherwise known as the '4-A's Framework' for education. 70

The 4-A's Framework is an international guide to determining the adequacy of the content of basic education. It is the minimum core or raison d'etre of basic education. ${ }^{71}$ Which is to say, if basic education is to claim its continued existence as an 'adequate education', it must at all costs and times exhibit these four features prescribed in the framework. ${ }^{72}$ An action or inaction that results in education falling short of any of the above features in the framework violates the right to basic education. ${ }^{73}$ It is essential to shortly examine the meaning of each ' $A$ ' in the framework. 'Availability' of education means that educational institutions and programs necessary for learning have to be available sufficiently to all learners. ${ }^{74}$ This feature is satisfied when government creates functioning educational institutions, by among other things supplying sanitation facilities for both sexes, safe drinking water, trained teachers on domestically competitive salaries, and teaching materials; to name a few. ${ }^{75}$ An 'Accessible' education is one that is non-discriminatory and physically reachable to all learners. ${ }^{76}$ Accessibility has been interpreted as constituting three fundamental components, including: (1) Non-discrimination, which means education must be accessible to all, especially the most vulnerable groups, without discrimination on any of the prohibited grounds; (2) Physical accessibility, which means that education must be within a safe physical reach, either by attendance at some reasonably convenient geographic location or via modern technology; and (3) Economic accessibility, which means that education must be affordable to all. ${ }^{77}$ An 'Acceptable' education refers to an education whose form and substance, including curricula and teaching methods, are acceptable to students and in some cases, their parents as well. ${ }^{78}$ The requirement of acceptability extends also to the question of the relevance and cultural appropriateness of the education. ${ }^{79}$ Regarding 'Adaptability', the government is required to develop policies and programs that it can adapt to the needs of changing societies and

69 As above.

70 As above.

71 Boezaart (n 65 above) 519

72 As above.

73 I Currie and J De Waal The Bill of Rights Handbook (2005) 133.

74 CECSR General Comment 16(6)(a); Boezaart (n 65 above) 518.

75 McConnachie (n 44 above) 23.

76 CECSR General Comment 16(6)(b); Boezaart (n 65 above) 518.

77 McConnachie (n 44 above) 23.

78 CECSR General Comment 16(6)(c).

79 As above. 
communities, and responds to the needs of students within their diverse social and cultural settings, including those learners who have disabilities. ${ }^{80}$ This framework consists of the standards that have to be used to determine the adequacy of education in context of the $4^{\text {th }}$ IR. Requisite curriculum, infrastructure, learning tools, trained teachers etc. have to align themselves to the educational needs resultant of the $4^{\text {th }} I R$. Otherwise, our education is devoid of its minimum core.

It is important to also determine the nature of the corresponding obligation of the state in the provisioning of this 'basic education'. The right to basic education encompasses both a negative and positive obligation of government for its realisation. ${ }^{81}$ The positive obligation modelled by the right to education is among the reasons why it is distinct from other socio-economic rights. ${ }^{82}$ The wording of this right is said to reflect a strong, unqualified right; free from promises and aspirational language. ${ }^{83}$ There are a number of reasons that justify the right to education having such a strong characterisation.

First, in Ex Parte Gauteng Provincial Legislature: In re Dispute Concerning the Constitutionality of Certain Provisions of the Gauteng School Education Bill of $1995,{ }^{84}$ the Constitutional Court held that section $32(a)$ in the Interim Constitution, ${ }^{85}$ the predecessor of section 29(1)(a) of the Final Constitution, created a 'positive right that basic education be provided for every person and not merely a negative right that such person should not be obstructed in pursuing his or her basic education'. ${ }^{86}$ Given the identical wording of the two aforementioned sections, the characterisation which applied to the former should apply to the latter as well. ${ }^{87}$

Secondly, in Government of the Republic of South Africa and others $v$ Grootboom and others, ${ }^{88}$ the Constitutional Court explained that the inclusion of the word 'access', as in the case of section 26 of the Constitution which provides for the right to access to housing, means that the state could fulfil its constitutional obligation by merely enabling people to provide for their own housing. ${ }^{89}$ The state is only obliged to create conducive conditions for access. ${ }^{90}$ The

80 CECSR General Comment 16(6)(d).

81 As above.

82 Woolman and Bishop (n 15 above) 57.9.

83 Skelton (n 30 above) 404.

841996 (3) SA 165 (CC).

85 Constitution of the Republic of South Africa, Act 200 of 1993, sec 32(a) of the Interim Constitution provided that 'Everyone shall have the right- (a) to basic education and to equal access to educational institutions'.

86 Woolman and Bishop (n 28 above) 57.8 .

87 As above.

88200011 BCLR 1169 (CC); Minister of Health and others $v$ Treatment Action Campaign and others (no 2) 2002 (5) SA 721 (CC).

89 Woolman and Bishop (n 15 above) 57.10

90 As above. 
corollary meaning, therefore, must be that the absence of the word 'access' in section 29(1)(a) means that over and above granting access, which is a negative obligation, the state must itself, provide the basic education to all. ${ }^{91}$ Ergo, the government must create new ways of educating as far as may be necessary in light of the evolving societal needs and not just give access to education in its current shape or form. The latter is a more passive obligation.

Thirdly, the right to basic education is distinct from the species of socio-economic rights exemplified by the cases of Grootboom and Treatment Action Campaign, whose realisation is made subject to limitations such as 'reasonable legislative measures'. ${ }^{92}$ This limitation does not apply when it comes to the right to basic education. Basic education can only be realised when its core content are provided and no reasonable measure is required. ${ }^{93}$ This right is not contingent on the availability of resources for its realisation. ${ }^{94}$ Whether the state claims that it does not have enough resources to fulfill its constitutional obligation or not, it is not released from its duties as imposed by this right. ${ }^{95}$ Finally, the right to education is not subject to progressive realisation. ${ }^{96}$ In Grootboom, Yacoob J described progressive realisation in the following terms: ${ }^{97}$

It means the accessibility should be progressively facilitated: legal, administrative, operational and financial hurdles should be examined and, where possible, lowered over time. Housing must be made more accessible to ... people as time progresses.

The right to education in the Constitution is not a right that can be made gradually available to more people 'over time'.${ }^{98}$ In JumaMusjid the Court asserted that ${ }^{99}$

the right to a basic education in section 29(1)(a) may be limited only in terms of a law of general application which is "reasonable and justifiable in an open and democratic society based on human dignity, equality and freedom". This right is therefore distinct from the right to 'further education' provided for in section 29(1)(b). The state is, in terms of that right, obliged, through reasonable measures, to make further education progressively available and accessible.

Therefore, the right to education can only be provided for when its minimum core is made available to all learners today.

91 As above.

92 Woolman and Bishop (n 15 above) 57.10.

93 As above.

94 As above.

95 As above.

96 As above.

97 Grootboom (n 88 above) para 45; M Seleoane 'The right to education: Lessons from Grootboom' (2003) 7(1) Law, Democracy and Development 137, 140-142; Woolman and Bishop (n 15 above) 57.10.

98 Woolman and Bishop (n 15 above) 57.10.

99 JumaMusjid (n 24 above) para 37. 


\section{Role of courts in realising basic education}

The role of courts in the enforcement and realisation of the right to basic education - an unqualified, immediately realisable right as envisaged in our Constitution - must be perceived through the lens of the phenomenon of the separation of powers. The separation of powers doctrine is a strong precept ingrained in our South African constitutional democracy which involves the impartation of separate powers to various arms of government. ${ }^{100}$ The doctrine ensures the protection of individual rights by way of the distribution of political power between different institutional actors, and includes mechanisms to ensure that such power is not unduly exercised. ${ }^{101}$ There is no doubt of the merits of the operation of this doctrine, especially in curtailing the violation of human rights that would otherwise ensue from the abuse of excessive concentration of power. ${ }^{102}$ The second rationale for separation of powers - in addition to the latter - is that functional distribution leads to specialisation which, in turn, enhances state efficiency. ${ }^{103}$ Thus, when specific functions, duties and responsibilities are allocated to distinctive institutions with areas of competence and jurisdiction, state efficiency typically creases. ${ }^{104}$

In South Africa, the delivery of the right to basic education involves all arms and spheres of government. ${ }^{105}$ The legislature establishes the legislative framework, the executive puts practical measures in place to ensure the realisation of the right, and where the executive fails to carry out its mandate, the judiciary is engaged to hold the latter to account. ${ }^{106}$ In our constitutional democracy, the judiciary also has the power to strike down laws as invalid if they are in conflict with the Constitution. ${ }^{107}$ The separation of powers delineates the terrain within which all the branches of the state should exercise their functions and thus it imposes a responsibility on each branch to guard itself against encroaching upon the functions of another branch. ${ }^{108}$ In relation to the judiciary, this doctrine means, before handing down any order, or granting any relief, courts must always and consciously endeavour to find the exact point at which

100 Ex Parte Chairperson of the Constitutional Assembly: In Re Certification of the Constitution of the Republic of South Africa 19964 SA 744 (CC), Skelton (n 30 above) para 393.

101 Skelton (n 30 above) 393.

102 S v Dodo 2001 (3) SA 382 (CC) para 8.

103 Skelton (n 30 above) 393.

104 As above. 2016 (4) SA 63 (SCA) para 41.

105 As above.

106 As above.

107 As above.

108 As above. 
their power begins and where such power terminates. ${ }^{109}$ This, to avoid the undesired amalgamation with the powers of other spheres of government. 110

The Constitutional Court has held that the judiciary should 'be slow to impose obligations upon government which will inhibit its ability to make and implement policy effectively'. ${ }^{111}$ The rationale for this is that courts are generally not possessed of the requisite expertise or do not have the advantage of ready access to sources of information necessary for decision-making and are thus required to acknowledge their own limitations. ${ }^{112}$ The effort by the courts not to interfere with the pre-eminent domain of the executive has been particularly tested in the enforcement of socio-economic rights which, like the right to basic education, reflect a positive, direct, strong, and unqualified right. ${ }^{113}$ In Soobramoney $v$ Minister of Health (Kwazulu-Natal), ${ }^{114}$ the first decision in which a substantive socioeconomic right was at issue, the Constitutional Court demonstrated extra caution against intruding into the domain of the executive, in that it failed to give content to the right that was at issue. In subsequent judgments, the Constitutional Court has time and again rejected contentions relating to the content of the minimum core of a right, holding that it is not appropriate for it to give content to what constitutes sufficient provision of a right as this was outside the purview of its domain and a matter best left to the executive.

Examples of cases where the Constitutional Court has been criticised for failing to take the opportunity to give substantive content to rights in question include: Treatment Action Campaign, ${ }^{115}$ and Grootboom. ${ }^{116}$ These cases exemplify the reluctancy of courts to adjudicate a transformational case involving socio-economic rights interpretation. This reluctancy is due, in part, to cautious observance of the separation of powers. Extrapolating on this issue, Sachs J stated that the large number of interlocking and interacting interests and considerations, including, political compromises, cost-benefit analysis, budgetary priority decisions, etc, which determine how best to realise values articulated in the constitution, are far better left in the hands of the executive rather than the judiciary. ${ }^{117}$ In Grootboom it was decided that, while there might be a 'core' responsibility

109 S Seedorf and S Sibanda 'Separation of Powers' in S Woolman and others (eds) Constitutional law of South Africa (2013 $2^{\text {nd }}$ edition) 1212.56.

110 As above.

111 Premier, Mpumalanga $v$ Executive Committee of State-aided Schools, Eastern Transvaal 1999 (2) SA 91 (CC) para 41.

112 Gauteng Gambling Board v Silverstar Development Ltd 2005 (4) SA 67 (SCA) para 29.

113 Seedorf \& Sibanda (n 109 above) 12-62.

1141998 (1) SA 765 (CC).

115 Treatment Action Campaign (n 87 above) paras 33-38.

116 Grootboom (n 87 above) para 33.

117 Du Plessis v De Klerk (CC) 1996 (3) SA 850 (CC) para 180. 
resting on the state, people are not entitled to demand - via courts at least - the direct delivery of such 'core' services. ${ }^{118}$ This was reiterated in the Treatment Action Campaign case where the Court stated that 'it is impossible to give everyone access to a 'core' service immediately'. ${ }^{119}$ Berger gives reason to why this alleged 'impossibility' in providing for a right immediately would potentially limit a courts interpretation of the same. He alludes that to proclaim impossible standards would cheapen the Constitution as and when people begin to realise that those standards do not improve their lives. ${ }^{120}$ The foregoing exposition of the Constitutional Court's existing socio-economic rights jurisprudence indicate that courts are inclined to limit the impact of both qualified and unqualified socioeconomic rights. ${ }^{121}$ Similarly, Woolman and Bishop predict, based on the current jurisprudence, that the courts might not be willing to give full content to the right to basic education. ${ }^{122}$ Berger argues that this is because a narrow interpretation of the constitution is better than an empty one. ${ }^{123}$ Which is to say it is better to read the unqualified right to basic education, for example, in such a way that it promises very little rather than too much.

In South Africa, we do not follow an absolutist approach to separation of powers. ${ }^{124}$ The political settlement of the Republic of South Africa at the end of the era of Apartheid was an inauguration of courts as being among important law-making sites for the democratic transition. The introduction of a justiciable Bill of Rights, a culture of justification, the doctrine separation of powers involving a system of checks and balances, and the demise of sovereignty of Parliament in exchange for a supreme constitution and concomitant, albeit to an unknown extent, increase in the law-making powers of the judiciary, are among indicators of South Africa's faith in the institution of the judiciary. A huge part of socio-economic as well as socio-political shift in South Africa, whether for the societal good or bad, depends on the efficacy of the institution of the judiciary becoming alive as holders of their responsibilities. In the context of enforcement of socioeconomic rights, this increase in judicial power will require courts to tread a fine line in abiding by the separation of powers. It must be noted, however, that the involvement of the judiciary in policymaking is not an all-or-nothing issue. ${ }^{125}$ Upholding the separation of powers

118 Grootboom (n 87 above) para 33.

119 Treatment Action Campaign (n 87 above) paras 26 and 39.

120 E Berger 'The Right to Education Under the South African Constitution' (2003) 103 Columbia Law Review 642. Woolman and Bishop (n 15 above) 57.11.

121 Woolman and Bishop (n 15 above) 57.11.

122 Woolman and Bishop (n 15 above) 57.13.

123 Berger (n 120 above) 642.

124 Justice Alliance of South Africa $v$ President of the Republic of South Africa 2011 (5) SA 388 (CC) para 33.

125 D Bilchitz 'Health' in S Woolman and others (eds) Constitutional Law of South Africa (2005 2nd edition) 56A.24. 
does not mean courts are completely barred from actively partaking, albeit with caution, in the insurance of the realisation of the right to a basic education for South Africa's children. ${ }^{126}$

Certainly, there are instances where the judiciary will be required to vindicate socio-economic rights. In getting involved, the courts have to interrogate, inter alia, the reasonableness of the policies adopted. ${ }^{127}$ A formal or strict approach to the separation of powers, with courts refusing to engage in the interpretation of core standards of a right, means that in an inquiry into the reasonableness of a given policy, 'reasonableness' will stand for whatever the court regards as desirable in that given context. ${ }^{128}$ Which is problematic as it leaves courts without clear, consistent and principled jurisprudential basis upon which to found decisions on socio-economic rights. ${ }^{129}$ Furthermore, given the ambiguity of the judiciary in such cases, courts may fail to intervene in the enforcement of socio-economic rights even when it is necessary to do so, and their orders may lack practical efficacy. ${ }^{130}$ In Bel Porto School Governing Body and Others $\checkmark$ Premier of the Western Cape Province and Another, ${ }^{131}$ Mokgoro and Sachs JJ argued that: ${ }^{132}$

while courts should exhibit deference towards the administration and recognise the practical difficulties which the administration faces, it could create a misleading impression that in instances where there is an infringement of a constitutional right, and there are significant practical difficulties in remedying the injustice caused, a decision-maker will not be held to account.

The empirical question of whether it is possible to provide the minimum benefit envisaged by the right immediately to everyone affected should not hinder the correct interpretation of the values in the constitution. ${ }^{133}$ Bilchitz argues, in the relationship between the content of and limitations on the right, that the process of defining the content of a right should be done independently of the consideration of the availability of resources. ${ }^{134}$ He provides three justifications for this claim: First, the recognition of an existing entitlement entails that the government is required to modify the status quo so as to fulfil people's rights as soon as possible. Secondly, the continued existence of these entitlements can influence the behaviour of those who have resources available but are not legally obliged to provide for those suffering from deprivation. Finally,

126 Skelton (n 30 above) 407

127 Bilchitz (n 125 above).

128 Bilchitz (n 125 above).

129 As above.

130 Bilchitz (n 125 above).

1312002 (3) SA 265 (CC).

132 Bel Porto School Governing Body and Others (n 131 above) para 62.

133 Seleoane (n 97 above) 153.

134 Bilchitz (n 125 above) 56A.40. 
recognising that a right exists even when not fulfilled entails that, as soon as resources do become available, the government is required to act in order to realise the rights that have been abrogated. ${ }^{135}$ However, this does not mean that the right to education is without limitation: the right to a basic education is capable of being limited in terms of section 36 of the Constitution or through a creative remedy. 136

Given the dawn of the $4^{\text {th }} I R$, the financial impact the interpretation of the right to basic education could have, and the current jurisprudence as delineated above: it is doubtful that courts will become involved in the assessment of the quality or adequacy of education in context of the $4^{\text {th }}$ IR. Will the judiciary, as it has before, regard the matter relating to provisioning education for the $4^{\text {th }}$ IR as the 'core content' of the right to basic education, and thus a question falling within the terrain of the executive? Is this an area in which the courts will show deference on the basis that the executive, rather than the judiciary, has the appropriate knowledge to determine adequacy of educational provisioning? Suppose the executive fails to provide adequate education required by the $4^{\text {th }} I R$, will the judiciary hold the latter to account? A particularly heavy responsibility on the courts to be sensitive to considerations of institutional competence and separation of powers can, sometimes, be used to avoid holding other spheres of government to account. ${ }^{137}$ In this respect, undue judicial adventurism, which is curtailed by separation of powers, can be as damaging as excessive judicial timidity. ${ }^{138}$ Judicial timidity implies that a court hides mousy and irresolutely behind the veil of the separation of powers, failing in their role of adjudicating for positive and immediately realisable rights. ${ }^{139}$ The doctrine of the separation of powers is not an abortion of the role of courts as overseers who ensure that all exercise of governmental power is in line with the Constitution. ${ }^{140}$ The separation of powers doctrine importantly involves the principle of checks and balances where each branch of government is assigned special powers in order to keep a check on the exercise of the functions of other branches. ${ }^{141}$ A sense of balance is needed to determine when it is suitable to defer to other branches of government and when courts have to step in to cure a constitutional wrong. ${ }^{142}$

135 As above.

136 Skelton (n 30 above) 407

137 As above.

138 Prince v President, Cape Law Society \& Others 2002 (2) SA 794 (CC) paras 155-156.

139 As above.

140 As above.

141 As above.

142 Seedorf \& Sibanda (n 109 above) 12-56. 


\section{Conclusion}

Whether we accept this or not, the $4^{\text {th }}$ IR is undoubtedly true to life and it is upon us. In a report reviewing how technological transformation, among other factors, is shaping skills demand and which was prepared by the International Labour Organisation(ILO) and Organization for Economic Co-operation and Development (OECD), South Africa was one of the countries observed to be experiencing the most critical shortages in skills needed in this new digital age. ${ }^{143}$ If South Africa is already proven to be in shortage of skills listed as essential for the $4^{\text {th }} I R$, the call for skills development is of utmost urgency.

Education must provide for skills development to empower people to navigate this new world introduced by the $4^{\text {th }}$ IR. The Constitutional Court in Christian Education South Africa v Minister of Education, ${ }^{144}$ stated that education must be flexible so that it can adapt to the changing needs of learners due to changes in society. ${ }^{145}$ Adaptability as a requirement for education (one of the 4-A's) speaks to the content of such education and the means used to deploy it. ${ }^{146}$ In this regard, Woolman and Bishop point out that 'the advent, and ubiquity of computer technology probably requires that learners leave school properly equipped for the modern society and work environment'. ${ }^{147}$

As delineated above, the right to basic education is not subject to a reasonableness standard, or availability of resources or progressive realisation. Seen in this light, this right to education is capable, if allowed, of preparing us for and leading us to the new dawn of the $4^{\text {th }}$ IR. With this entitlement, the government can be persuaded (or ordered) by courts to make all the changes which are necessary to fully realise the right to basic education for the $4^{\text {th }}$ IR. Regrettably, litigation of such a right is easier said than done.

The assessment of the quality or adequacy of education seems to be a terrain courts in South Africa have been reluctant to engage in and it seems that in the debate regarding the 'core content' of the right to education, courts will show deference on the basis that the executive, rather than the judiciary, has the appropriate knowledge to assess adequacy of the content of a right. ${ }^{148}$ Thus, even though this right is unqualified ex lege, it is not obvious that the right can be immediately realisable de facto. Courts are reluctant to stretch their interpretative powers in holding that certain rights are immediately

143 ILO and OECD Report (n 3 above) 12.

1442000 (4) SA 757 (CC).

145 As above.

146 Woolman and Bishop (n 15 above) 57.

147 As above.

148 Skelton (n 30 above) 405. 
realisable; ${ }^{149}$ especially if it involves positive timeous measures required to be taken by another sphere of government. ${ }^{150}$ The Constitutional Court in Premier, Mpumalanga v Executive Committee of State-aided Schools, Eastern Transvaal, ${ }^{151}$ held that for the sake of 'procedural fairness in a given case, a court should be slow to impose obligations upon government which will inhibit its ability to make and implement policy effectively'. ${ }^{152}$ This means that the courts will be less inclined to interpret the right to basic education as one that is immediately and positively realisable. Put differently, the courts will not order government to provide adequate education for the $4^{\text {th }}$ IR immediately.

The Constitutional Court's now well-established approach to these rights is to measure the 'reasonableness' of the plans and measures that the other arms of government have taken towards fulfilment of their obligation. If the measures are found to be reasonable, heedless of the adequacy of the same, the government will have fulfilled its obligation. This self-imposed restraint has been criticised, particularly the Constitutional Court's refusal to involve itself in determining the core content of socio-economic rights, preferring instead to apply a rationality review that focuses on a justification analysis without a detailed analysis of the right. ${ }^{153}$ However, criticism notwithstanding, the Court reiterated in Mazibuko $v$ City of Johannesburg that it will not engage in detailed debates about the content of rights. ${ }^{154}$ What it will do is call upon the government to explain why the policy is reasonable and to disclose how the policy was formulated - including what investigation and research was undertaken, what alternatives were considered and why the particular option was selected. ${ }^{155}$ The Court also stated that the Constitution does not hold government to impossible standards of perfection, and that the courts will not take over tasks that in a democracy should be left to other arms of government. ${ }^{156}$

With how courts have constrained themselves, it seems that when the need for adjudicating for changes in the provisioning of education for the $4^{\text {th }}$ IR, courts will be faced with a tremendous challenge. The $4^{\text {th }}$ IR poses a challenge to courts to adjudicate for the immediate provisioning of education, otherwise we will fail to produce leaders, breadwinners, employers and employees equipped to navigate this new world.

149 Skelton (n 30 above) 395.

150 Skelton (n 30 above) 393.

1511999 (2) SA 91 (CC).

1521999 (2) SA 91 (CC) para 41.

153 Skelton (n 30 above) 406.

1542010 (4) SA 1 (CC) para 68.

155 As above.

156 As above. 